Review Article

\title{
Biological Activity, Hepatotoxicity, and Structure-Activity Relationship of Kavalactones and Flavokavins, the Two Main Bioactive Components in Kava (Piper methysticum)
}

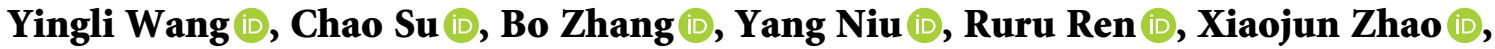

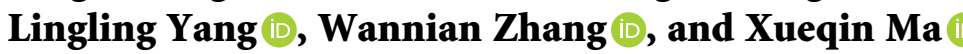 \\ Department of Pharmaceutical Analysis, School of Pharmacy, Key Laboratory of Hui Ethnic Medicine Modernization, \\ Ministry of Education, Ningxia Medical University, 1160 Shenli Street, Yinchuan 750004, China \\ Correspondence should be addressed to Xueqin Ma; maxueqin217@126.com
}

Received 11 June 2021; Accepted 13 August 2021; Published 23 August 2021

Academic Editor: Daniela Rigano

Copyright (c) 2021 Yingli Wang et al. This is an open access article distributed under the Creative Commons Attribution License, which permits unrestricted use, distribution, and reproduction in any medium, provided the original work is properly cited.

\begin{abstract}
Kava (Piper methysticum Forst) is a popular and favorable edible medicinal herb which was traditionally used to prepare a nonfermented beverage with relaxant beneficial for both social and recreational purposes. Numerous studies conducted on kava have confirmed the presence of kavalactones and flavokawains, two major groups of bioactive ingredients, in this miraculous natural plant. Expectedly, both kavalactone and flavokawain components exhibited potent antianxiety and anticancer activities, and their structure-activity relationships were also revealed. However, dozens of clinical data revealed the hepatotoxicity effect which is indirectly or directly associated with kava consumption, and most of the evidence currently seems to point the compounds of flavokawains in kava were responsible. Therefore, our aim is to conduct a systematic review of kavalactones and flavokawains in kava including their biological activities, structureactivity relationships, and toxicities, and as a result of our systematic investigations, suggestions on kava and its compounds are supplied for future research.
\end{abstract}

\section{Introduction}

Piper methysticum Forst, popularly known as kava, is an edible and medicinal plant of shrub which has history of more than 2000 years. Given the purposes for religious occasions, medicinal purposes, and social gatherings [1-3], kava is particularly important for the indigenous people of the Pacific Rim and the Hawaiian Islands [4]. In the daily life of the South Pacific island people, the water infusion of kava root was used as a traditional beverage since ancient times for its sedative and calming effects, such as soothing the nerves, inducing relaxation and sleep, counteracting fatigue, and reducing weight $[5,6]$, and the dietary supplements of kava were easily obtained in some health food stores [7]. Similarly, in the Western world, pharmaceutical preparations of this herb were commonly applied for the treatment of anxiety disorders.
However, there was compelling evidence that kava consumption was related to some toxicities which led to its restriction or warning in many countries since $2002[8,9]$. Several studies have reported a series of adverse health effects including kava dermopathy [10], hepatotoxicity [11, 12], and the disruption of cognition $[13,14]$ which were associated with kava consumption. Among those, kava hepatotoxicity was the most concerning adverse effect of kava consumption.

Although several of the published reviews have summarized the pharmacology, safety profiles associated with kava $[3,9,15]$, however, over the past decades, dozens of studies which focused on the chemical constituents and biological activities of kava have been disclosed and some possible mechanisms of action have also been explored. Also, we found some scientific gaps still existed in the specific mechanism of its anticancer effect, as well as the 
detailed pathogenetic factors of kava hepatotoxicity, especially the flavokawain components which were believed to b responsible for the hepatotoxicity. Furthermore, the clinical evidence for the treatment of generalized anxiety disorder (GAD) and the responsibility components was also not clear. The aim of this paper is to give a full-scale profile for the research of kava kavalactones and flavokavins, focusing on their available scientific information including the chemical structures, structure-activity relationships, biological activities, and toxicities.

\section{Chemical Constituents}

Until now, more than 56 constituents have been isolated and identified from $P$. methysticum. These can be assigned to two main classes, kavalactones and flavokavins. The details of each type of compounds are summarized below.

2.1. Kavalactones. Kavalactones belong to lipophilic lactones with an $\alpha$-pyrone skeleton typically 4 -methoxy-2pyrones, and aromatic stiryl or phenylethyl was substituted at the 6-position [16]. At present, 29 kavalactones, shown in Figure 1, have been isolated and identified. Kavalactones can be extracted from the rhizomes, roots, and root stems of the plant [9]. By employing gas chromatography-mass spectrometer (GCMS) combined with high-performance liquid chromatography (HPLC) techniques, the extracting efficacies of different solvents (water, acetone, chloroform, methanol, ethanol, and hexane) on the contents of kavalactone constituents were determined [5], as Figure 2 shows. Seven major kavalactones, namely, methysticin (4), dihydromethysticin (5), kavain (6), 7, 8-dihydrokavain (7), desmethoxyyagonin (9), yangonin (10), and 5,6dihydro-5,6-dehydrokavain (19), were obtained from the kava roots. It was found that acetone was the most effective solvent in terms of yield and quantities of kavalactone compounds obtained. The contents of seven major kavalactones including methysticin dihydromethysticin, kavain, 7, 8-dihydrokavain, desmethoxyyagonin, yongonin, and 5,6-dihydro-5,6-dehydrokavain were $1.2-14.4 \mathrm{mg} / \mathrm{g}, 3.2-51.9 \mathrm{mg} / \mathrm{g}, 3.3-41.5 \mathrm{mg} / \mathrm{g} 3.8-55.1 \mathrm{mg} /$ g, $2.1-21 \mathrm{mg} / \mathrm{g}, 2.1-84.1 \mathrm{mg} / \mathrm{g}$, and $1.9-27.1 \mathrm{mg} / \mathrm{g}$, respectively [5].

A series of kavalactone dimers were also isolated and identified via extensive phytochemical investigation on the roots of kava [17-19]. By using classical chromatographic separation methods combined with spectrum identification techniques, a series of novel dimeric kavalactones, namely, diyangonins A (20), diyangonins B (21), diyangonins C (22), yangonindimers A (23), yangonindimers B (24), yangonindimers $C$ (25), kavalactone A (26), aniba-dimer A (27), rel-, trans-3-bis[6-(4-methoxy-2-pyronyl)]-cis-2, trans -4diphenyl cyclobutane (28), and 6,6'-(3,4-diphenylcyclobutane-1,2-diyl) bis (4-methoxy-2H-pyran-2-one) (29), were isolated and elucidated from kava [17-19]. The chemical structures of compounds 20-29 are listed in Figure 1.
2.2. Flavokavins. The first three dihydrochalcones, namely, flavokavin A (30), flavokavin B (31), and flavokavin C (32), were isolated from the roots of kava by using the highperformance thin-layer chromatography (HPTLC) method [20]; followed by the pinostrobin chalcone (33), which was detected in kava roots for the first time by employing GCMS and HPLC analysis [5]. Recently, two new flavanones, namely, pinostrobin (34) and 5,7-dimethoxyflavanone (35) [21], along with 5,7-dihydroxy-4'-methoxy- 6,8dimethylflavanone (matteucinol,36) and 5-hydroxy- $4^{\prime}, 7$ dimethoxyflavanone (37) have been obtained via column chromatography (CC) and HPLC methods [5, 22]. The chemical structures of these flavanones are listed in Figure 3.

\section{Biological Activities}

Various uses and pharmacological properties of the isolated kavalactones and flavokavins from the rhizomes and roots of kava have been reported (Table 1; Figure 4). Lately, a published review has summarized the anti-inflammatory activity, neurological functions, and anticancer property of kava and its components [58]. To avoid repetition and exhibit our innovation, we supplied the details about the abovementioned activities of kavalactones and flavokavins, including the in vitro cell models and in vivo animal models, the methods of the experiments, the major findings, and the possible mechanisms, for example, the anti-inflammatory mechanisms of FKA, as Figure 5 shows, and the anticancer mechanisms of DHM, as Figure 6 described. All of them are exhibited in Table 1 and Figures 4-6.

\section{Kava Hepatotoxicity}

Kava became a well-known edible medicinal herb not only for its excellent activity but also for its controversy toxicity, and kava hepatotoxicity was the most concerning adverse effect of kava consumption [11]. Since the first case of kava hepatotoxicity was reported by in 1998 [59], more than 100 cases of severe liver injury following kava exposure have been identified all over the world. However, many of which were uncertain whether kava was responsible or it was caused by the other possible pathogenetic factors which were overlooked in reported cases of kava hepatotoxicity. For example, kava consumption involved concomitant ingestion of other agents with potential hepatotoxicity including other medications and/or alcohol [9]. Furthermore, the number of cases might be overstated as the types of liver injury noted include necrosis, drug-induced hepatitis, and cholestatic hepatitis [3]. It was interesting to note that, in the South Pacific, the adverse effect of liver damage was virtually absent during kava consumption. Cytochrome P450 2D6 (CYP2D6), an important enzyme which was necessary during drug metabolism, could also mediate the drug-drug interactions and, thus, might be responsible [60]. During the past years, suggestions and discussions have revealed the possible pathogenetic factors leading to the development of kava hepatotoxicity [11], and the details are given in the following. 
<smiles>[R]c1ccc(CCC2OC(=O)C=C(C)C2[R])c([R3])c1[R]</smiles>

\begin{tabular}{|c|c|c|c|c|c|c|c|}
\hline No. & Compounds & $\mathrm{R}_{1}$ & $\mathbf{R}_{2}$ & $\mathbf{R}_{3}$ & $\mathbf{R}_{4}$ & $\mathrm{C}_{5}-\mathrm{C}_{6}$ & $\mathrm{C}_{7}-\mathrm{C}_{8}$ \\
\hline 1 & 11-Hydroxy-12-methoxydihydrokavain & $\mathrm{OCH}_{3}$ & $\mathrm{OH}$ & & & & \\
\hline 2 & 7,8-Dihydro-5-hydroxykavain & & & & $\beta-\mathrm{OH}$ & & \\
\hline 3 & 11,12-Dimethoxydihydrokavain & $\mathrm{OCH}_{3}$ & $\mathrm{OCH}_{3}$ & & & & \\
\hline 4 & Methysticin (M) & $\mathrm{OCH}$ & & & & & $=$ \\
\hline 5 & Dihydromethysticin (DHM) & $\mathrm{OCH}$ & & & & & \\
\hline 6 & Kavain $(\mathrm{K})$ & & & & & & $=$ \\
\hline 7 & 7,8-Dihydrokavain (DHK) & & & & & & \\
\hline 8 & 5,6-Dehydromethysticin & $\mathrm{OCF}$ & $\mathrm{H}_{2} \mathrm{O}$ & & & $=$ & $=$ \\
\hline 9 & Desmethoxyyagonin (DMY) & & & & & $=$ & $=$ \\
\hline 10 & Yangonin $(\mathrm{Y})$ & $\mathrm{OCH}_{3}$ & & & & $=$ & $=$ \\
\hline 11 & $5,6,7,8$-Tetrahydroyagonin & $\mathrm{OCH}_{3}$ & & & & & \\
\hline 12 & 5,6-Dihydroyagonin & $\mathrm{OCH}_{3}$ & & & & & $=$ \\
\hline 13 & 7,8-Dihydroyagonin & $\mathrm{OCH}_{3}$ & & & & $=$ & \\
\hline 14 & 10-Methoxyyagonin & $\mathrm{OCH}_{3}$ & & $\mathrm{OCH}_{3}$ & & $=$ & $=$ \\
\hline 15 & 11-Methoxyyagonin & $\mathrm{OCH}_{3}$ & $\mathrm{OCH}_{3}$ & & & $=$ & $=$ \\
\hline 16 & 11-Hydroxyyagonin & $\mathrm{OCH}_{3}$ & $\mathrm{OH}$ & & & $=$ & $=$ \\
\hline 17 & Hydroxykavain & & & & $\mathrm{OH}$ & & $=$ \\
\hline 18 & 11-Methoxy-12-hydroxydehydrokavain & $\mathrm{OH}$ & $\mathrm{OCH}_{3}$ & & & $=$ & $=$ \\
\hline 19 & 5,6-Dihydro-5,6-dehydrokavain (DDK) & & $\mathrm{OCH}_{3}$ & & & $=$ & \\
\hline
\end{tabular}

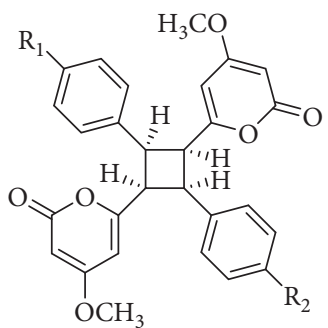

$20,21,28$

NO. Compounds

20 Diyangonins A

21 Diyangonins B

22 Diyangonins C

23 Yangonindimers A

24 Yangonindimers B

25 Yangonindimers $\mathrm{C}$

27 Aniba-dimer A

28

29<smiles>[R]c1ccc([C@H]2[C@H](C3=CC(OC)=CC(=O)C3)[C@H](c3cc(OC)cc(=O)o3)[C@H]2c2ccccc2)cc1</smiles>

22,29

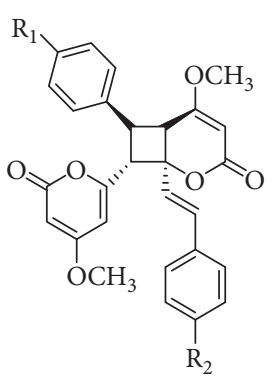

23-25,27<smiles></smiles>

26
$\mathbf{R}\left(\mathbf{R}_{1}\right) \quad \mathbf{R}_{2}$

$\mathrm{OCH}_{3} \quad \mathrm{OCH}_{3}$

$\mathrm{OCH}_{3} \quad \mathrm{H}$

$\mathrm{OCH}_{3}$

$\mathrm{OCH}_{3} \quad \mathrm{OCH}_{3}$

$\mathrm{OCH}_{3} \quad \mathrm{H}$

$\mathrm{H} \quad \mathrm{OCH}_{3}$

$\mathrm{H} \quad \mathrm{H}$

$\mathrm{H} \quad \mathrm{H}$

Figure 1: Chemical structures of compounds 1-29. 


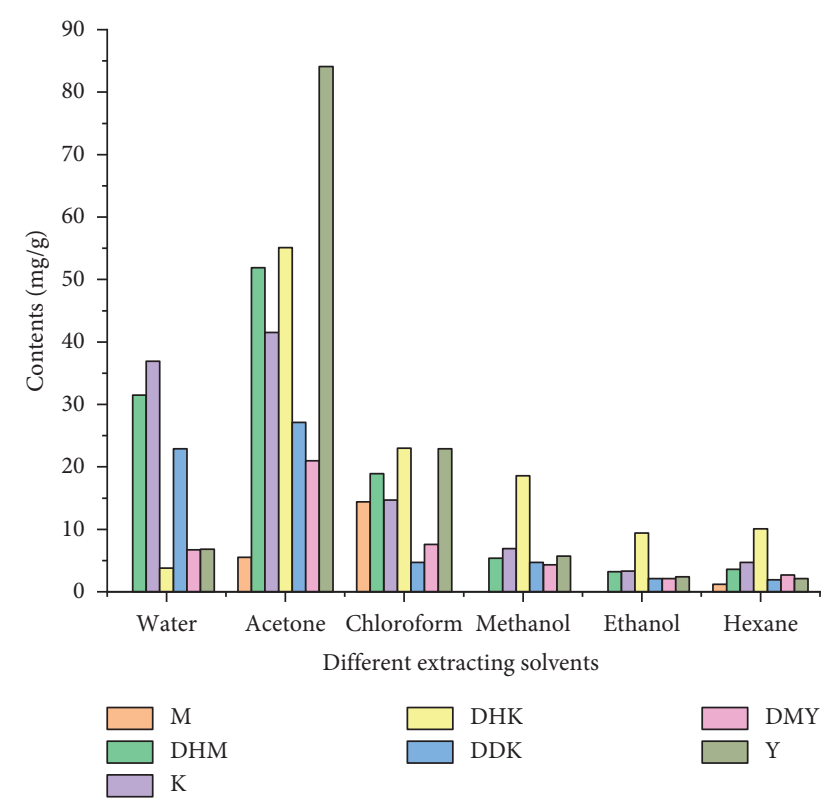

Figure 2: Content of seven major kavalactones in kava with different extracting solvents (mg/g extract).

4.1. Different Sources and Parts of Kava for Practical Applications. Concerning the early history of kava, the lack of standard kava raw material might be the major factor, at least in some cases [61]. The different parts of the kava plant possessed different compounds, which showed different kava raw materials might contain different contents of the toxic constituents and then influenced the function of liver [11], for example, the substandard kava cultivars, different growth ages, using stem peelings replaced kava toots, rhizomes, or aerial parts of the kava plants (contains toxic alkaloids), and contamination of aflatoxicosis or other mould hepatotoxins [61]. Therefore, the botanical characteristics of the plant and the harvesting and storage conditions might be involved in the development of hepatotoxicity and triggering idiosyncratic reaction $[11,62]$.

4.2. Different Solvents Used for Kava Extraction. The next concern was whether the liver is damaged following kava consumption due to the solvent used for kava extract preparation or not [11]. Because the kavalactone and flavokavins contained in kava possessed different polarities, employing ethanol and acetone as solvents for the extraction of kava generally yielded high contents of kavalactone. As the higher portions of kavalactones was proved to be usually associated with liver failure, thus, using acetone as the extracted solvent might concentrate the toxic components. However, the results came from the World Health Organization (WHO) study which reported five live injury cases which were associated with the aqueous extracts of kava. Therefore, the solvent itself fails to involve in the overall pathogenesis of kava hepatotoxicity $[11,60]$.

4.3. Comedication, Overdose, and Prolonged Use. In many kava hepatotoxicity cases, other concurrent medications being taken by patients also existed; thus, it was uncertain whether the hepatotoxic reaction was initiated by kava itself or other drugs. Theoretically, the metabolic process of complicated drugs might be altered in some especially cases, and even the components themselves lacking evidences of hepatotoxicity might also exert hepatotoxic effects. Therefore, at least in some clinical cases, the interaction between kava and drug might be a potential factor for the hepatotoxicity [11]. Furthermore, prolonged kava treatment as well as overdose of kavalactones should not be overlooked $[63,64]$. It was disclosed that nonadherence to medication was a common matter but not unique for kava treatment. However, at present, there are no studies that focus on the abovementioned subjects. Therefore, it was not available to answer the issue of kava hepatotoxicity that might be related with prolonged and overdose, and further experimental assessment was necessary.

4.4. Toxic Constituents, Metabolites, and Contaminations. Other unknown toxic components, the contaminations derived from various kava extracts, and storage process could not be excluded for the moment, for example, the piperidine alkaloid pipermethystine in aerial parts of the kava plants, the contamination of aflatoxicosis or other mould hepatotoxins $[11,65]$ during long time, and improper storage. It was proved that the alkaloid pipermethystine could induce liver cell death by glutathione (GSH) depletion and modulate MAPK and NF- $\kappa \mathrm{B}$ signaling pathways in vitro [66]. However, other in vivo experimental animal studies obtained the converse results, which failed to cause any liver damage during alkaloid pipermethystine treatment. Therefore, it was uncertain that pipermethystine had the responsibility between kava and hepatotoxicity [61, 66, 67]. In addition, FKB has been considered as a possible pathogenetic factor for human kava hepatotoxicity $[61,68]$. It could induce cell apoptosis in hepatoblastoma (HepG2) $\left(\mathrm{LD}_{50}=15.3 \pm 0.2 \mu \mathrm{M}\right)$ and $\mathrm{L}-02\left(\mathrm{LD}_{50}=32 \mu \mathrm{M}\right)$ cells via inducing oxidative stress, reducing the depletion of glutathione and inhibiting the $\mathrm{I}-\kappa \mathrm{B}$ kinase (IKK) activity in vitro [69]. FKB, meanwhile, induced hepatic damage by inhibiting $\mathrm{NF}-\kappa \mathrm{B}$ transcriptional activity in vivo $[61,68,69]$. Furthermore, kava hepatotoxicity also involved concomitant ingestion of other agents such as alcohol; thus, the metabolic interactions of kava with alcohol might also be a possible mechanism [70].

\section{The Investigation of the Structure-Activity Relationship (SAR)}

The structure-activity relationship study is a widely used and well-established method for the early drug discovery stage. The structural-based activity information was usually employed to screen for or optimize compounds to achieve drug-like properties [71]. Kavalactones and flavokawains possessed the unique pharmacological effects including the efficacy and side effects, which were all directly related to their structures [72]. Recently, different synthetic approaches of kavalactones, as well as the key 


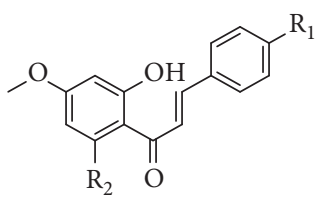

$\begin{array}{llll}\text { NO. } & \text { Compounds } & \mathbf{R}_{1} & \mathbf{R}_{2} \\ \mathbf{3 0} & \text { Flavokavin A } & \mathrm{OCH}_{3} & \mathrm{OCH}_{3} \\ 31 & \text { Flavokavin B } & \mathrm{H} & \mathrm{OCH}_{3} \\ 32 & \text { Flavokavin C } & \mathrm{OH} & \mathrm{OCH}_{3} \\ \text { 33 } & \text { Pinostrobin chalcone } & \mathrm{H} & \mathrm{H}\end{array}$

$\begin{array}{lllcccc}\text { NO. } & \text { Compounds } & \mathbf{R}_{\mathbf{1}} & \mathbf{R}_{2} & \mathbf{R}_{3} & \mathbf{R}_{4} & \mathbf{R}_{5} \\ 34 & \text { Pinostrobin } & & \mathrm{OCH}_{3} & & \mathrm{OH} & \\ 35 & \text { 5,7-dimethoxyflavanone } & & \mathrm{OCH}_{3} & & \mathrm{OCH}_{3} & \\ 36 & \text { 5,7-dihydroxy-4'-methoxy-6,8-dimethylflavanone } & \mathrm{CH}_{3} & \mathrm{OH} & \mathrm{CH}_{3} & \mathrm{OH} & \mathrm{OCH}_{3} \\ 37 & \text { 5-hydroxy-4',7-dimethoxyflavanone } & & \mathrm{OCH}_{3} & & \mathrm{OH} & \mathrm{OCH}_{3}\end{array}$

Figure 3: Chemical structures of compounds 30-37.

TABLE 1: The pharmacological activities of kavalactones and flavokavins in kava.

\begin{tabular}{|c|c|c|c|c|c|c|}
\hline $\begin{array}{l}\text { s. } \\
\text { no. }\end{array}$ & Activity/disesese & Active molecule(s) & Model system & Mechodsidosage & Result or major finding & Reference \\
\hline 1 & Sedative property & Kavain & Male Wistar rats & $\begin{array}{ll}\text { In vivo } & \text { Kavain 10, 30, and 100 mgkkg. p.o. suppended in } 0.5 \% \text { carboxymethy cellubses solution }\end{array}$ & 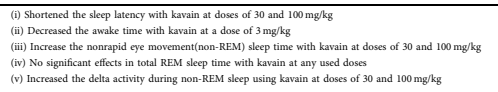 & [23] \\
\hline \multirow{5}{*}{2} & \multirow{3}{*}{ Anti-inflammatory activity } & Kavain & $\begin{array}{l}\text { Mouse maccrophages, mouse bone marrow macrophages (BMM), leukemia cells in mouse } \\
\text { macrophage (RAW 266.7 cells). THP-1 cells, and human peripheral blood mononuclear cells } \\
\text { (HPBMC); wild-type (WT) mice }\end{array}$ & 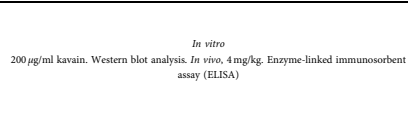 & 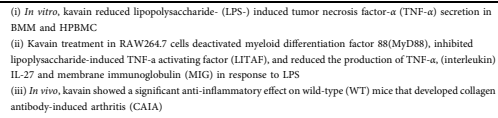 & [24] \\
\hline & & Kavain analogue (Kavool) & Mouse bone marrow macrophages (BMM) and THP-1 cells; wild-type (WT) mice & $\begin{array}{c}\text { In vitro and in vivo } \\
\text { Enzyme-linked immunosorbent assay, endotoxic chlock assay, western blot analysis, and } \\
\text { cytotoxicity tests }\end{array}$ & 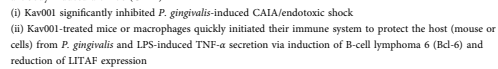 & [25] \\
\hline & & Flavokawain A (FKA) & RAW 264.7 c clls & 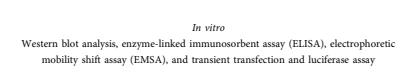 & 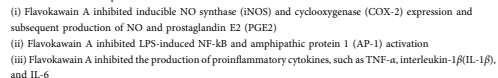 & [26] \\
\hline & Periodontitis & $\begin{array}{l}\text { Kava:24l compound (kavain } \\
\text { analogue }\end{array}$ & RAW 264.7 cells & $\begin{array}{l}\text { Kava-241 } 40 \text { mg/kg. In vitro, enzyme-linked immunosorbent assay (ELISA) and cytotoxicity } \\
\text { Kaya-2asay }\end{array}$ & 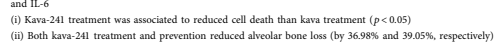 & [27] \\
\hline & Rheumatoid arthritis (RA) & $\begin{array}{l}\text { Kava-24l compound (kavain } \\
\text { analogue) }\end{array}$ & Pathogen-free DBA/BO male mice & $\begin{array}{l}\text { Kava-24l tomg vikg } \\
\text { Western blot analysis, enyyme-linked immunosorobent assay (ELISA), clinical inflammation }\end{array}$ & 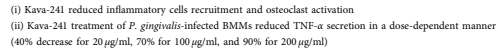 & [28] \\
\hline
\end{tabular}


TABle 1: Continued.

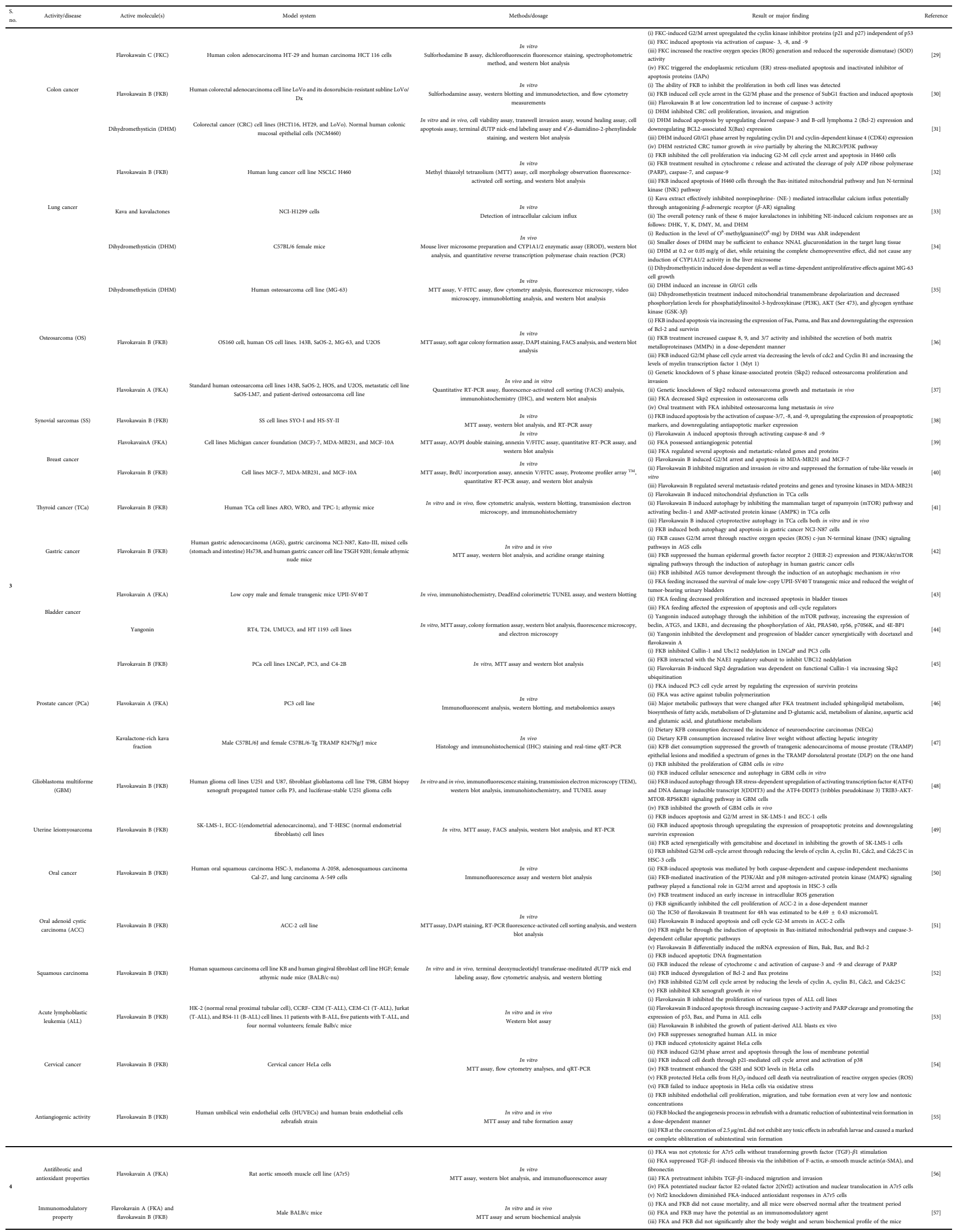




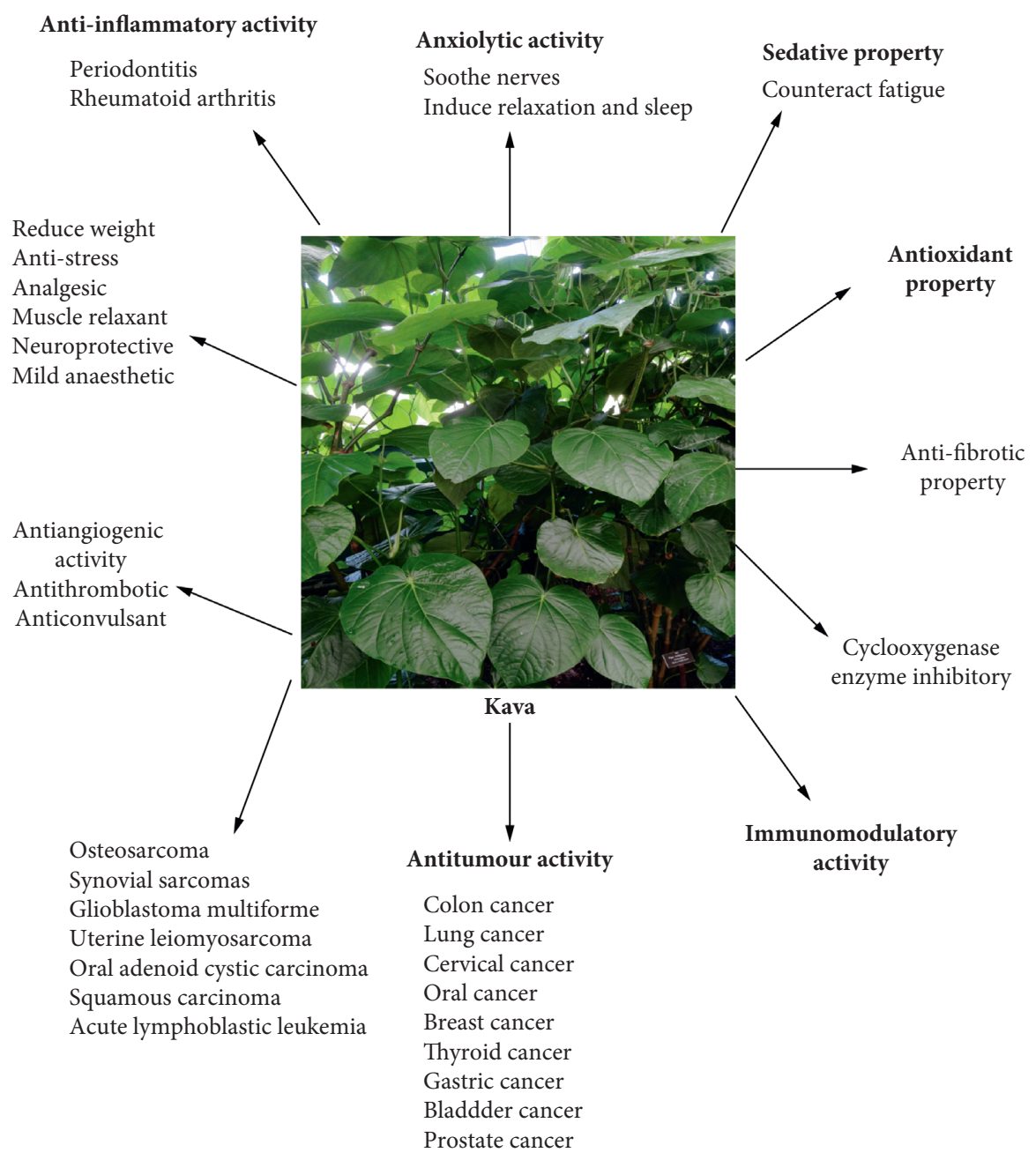

FIGURE 4: The pharmacological activities of kava.

biosynthetic enzymes of the kavalactone and flavokavain, were reported [73, 74]. However, the difficulty of biosynthetic and chemical synthesis hindered the therapeutic use of kavalactones and flavokawains in both laboratory experiments and clinical trials [74]. In order to improve the efficacy and pharmaceutical properties of kavalactones and flavokavins, further medicinal chemistry optimization is needed.

5.1. Kavalactone Analogues. Lately, it was explored that kavalactone analogues exhibited in vitro anthelmintic activities against Haemonchus contortus larvae [75]. Through the chemical modifications of 2-,3-, and 4-substituent on the pendant aryl ring (Figure 7), two kavalactones (yangonin and desmethoxyyangonin) and 17 analogues were synthesized. Among these analogues, compounds with 4-trifluoromethoxy, 4-phenoxy, 4-difluoromethoxy, and 4-Nmorpholine substitutions showed convinced anthelmintic activities $\left(1.9 \mu \mathrm{M}<\mathrm{IC}_{50}<8.9 \mu \mathrm{M}\right)$ which were superior to desmethoxyyangonin $\left(\mathrm{IC}_{50}=37.1 \mu \mathrm{M}\right)$ and yangonin $\left(\mathrm{IC}_{50}=15.0 \mu \mathrm{M}\right)$ and, thus, provided an opportunity for developing novel anthelmintic agents [75].
Besides kavalactone, kavain analogues were also designed and synthesized through chemical modifications. The results of pharmacodynamic tests showed that the synthesized compounds possessed anti-inflammation $[25,27,28,72,76]$ and analgesic activities [77]. Kava-241, a kavain-derived compound, showed convinced efficacy in the prevention or treatment of advanced periodontal inflammation and related alveolar bone destruction in vitro and in vivo $[27,28]$ and, thus, might be a promising therapeutic agent against periodontal diseases in the future. Kav001, another kavain analogue, was designed and synthesized through optimizing the biological activity and structural physicochemical properties of kavain [24, 25]. Expectedly, kav001 displayed stronger analgesic activity than kavain [77].

5.2. Flavokawain Derivatives. Chalcones, an $\alpha, \beta$-unsaturated ketone, was explored generally due to its simple chemistry structure, ease of synthesis, diversity of substituents, and wide range of biological activities [78, 79]. Flavokawain was a kind of chalcones which was widely occurring in plants [78]. Through chemical modifications of the A-ring $\left(\mathrm{R}_{1}\right.$ site $)$ 


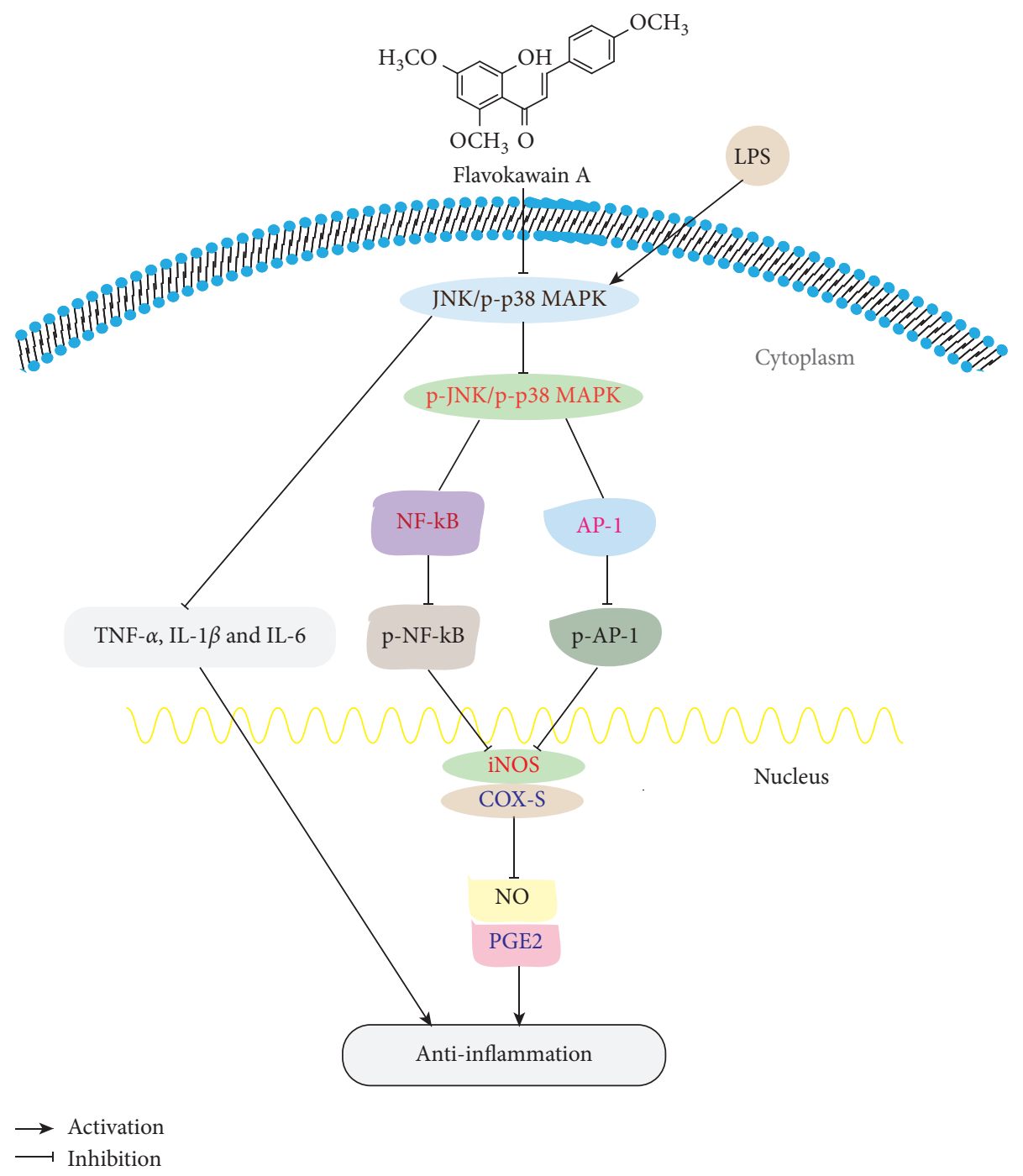

FIGURE 5: The proposed model of the FKA-mediated anti-inflammation via nuclear factor- $\kappa \mathrm{B}(\mathrm{NF}-\kappa \mathrm{B})$ blockade and AP-1 activation in RAW 264.7 macrophages.

and B-ring $\left(\mathrm{R}_{2}, \mathrm{R}_{3}\right.$, and $\mathrm{R}_{4}$ site) (Figure 8 ), several flavokawain derivatives were designed, synthesized, and characterized. The anticancer properties of flavokawain in kava have been estimated due to the presence of the $\alpha$, $\beta$-unsaturated ketone part through the structure-activity relationship studies of flavokawain derivatives [80]. The presence of electron-withdrawing and electron-donating groups could influence the effects of the $\alpha, \beta$-unsaturated system and then cause the change of cytotoxicity [81]. Meanwhile, the presence of a hydroxyl group on the A-ring, rather than the B-ring, made the flavokawain derivatives more stable $[80,81]$. Furthermore, effects of different functional groups were studied via substituent modification of the ortho, meta, and para positions on the B-ring. It was well established that the steric hindrance played a key role in the activity of flavokawain derivatives, which might exert cytotoxicity against cancer cell lines $[82,83]$. The structureactivity relationship studies of flavokawain derivatives indicated that trimethoxy of the A-ring showed the most convinced cytotoxicity and selectivity, followed by the modification of the meta position on the B-ring and the substitution of halogen groups [82]. For example, (E)-1-( $2^{\prime}$ hydroxy-4',6'-dimethoxyphenyl)-3-(4-methylthio) phenyl) prop-2-ene-1-one (FLS), a flavokawain derivative, showed good selectivity against the breast cancer MCF-7 cell line [84].

\section{Kava Metabolism}

The pharmacokinetics and pharmacodynamics studies of kava in humans were carried out by means of experiments involving self-medication [85]. In humans, kavalactones as well as their metabolites were generally eliminated in the urine and feces, and the peak plasma levels usually occur around $2 \mathrm{~h}$ after ingestion, with a half-life of about $9 \mathrm{~h}$. Orally administered kava water extracts were excreted mostly unchanged into urine [86]. The metabolism of kavain studied by the human liver cell-line Hep-G2 [87] or human serum and urine [85] disclosed the metabolites of kava including $\mathrm{p}$-hydroxykavain, p-hydroxy-7,8-dihydrokavain, 


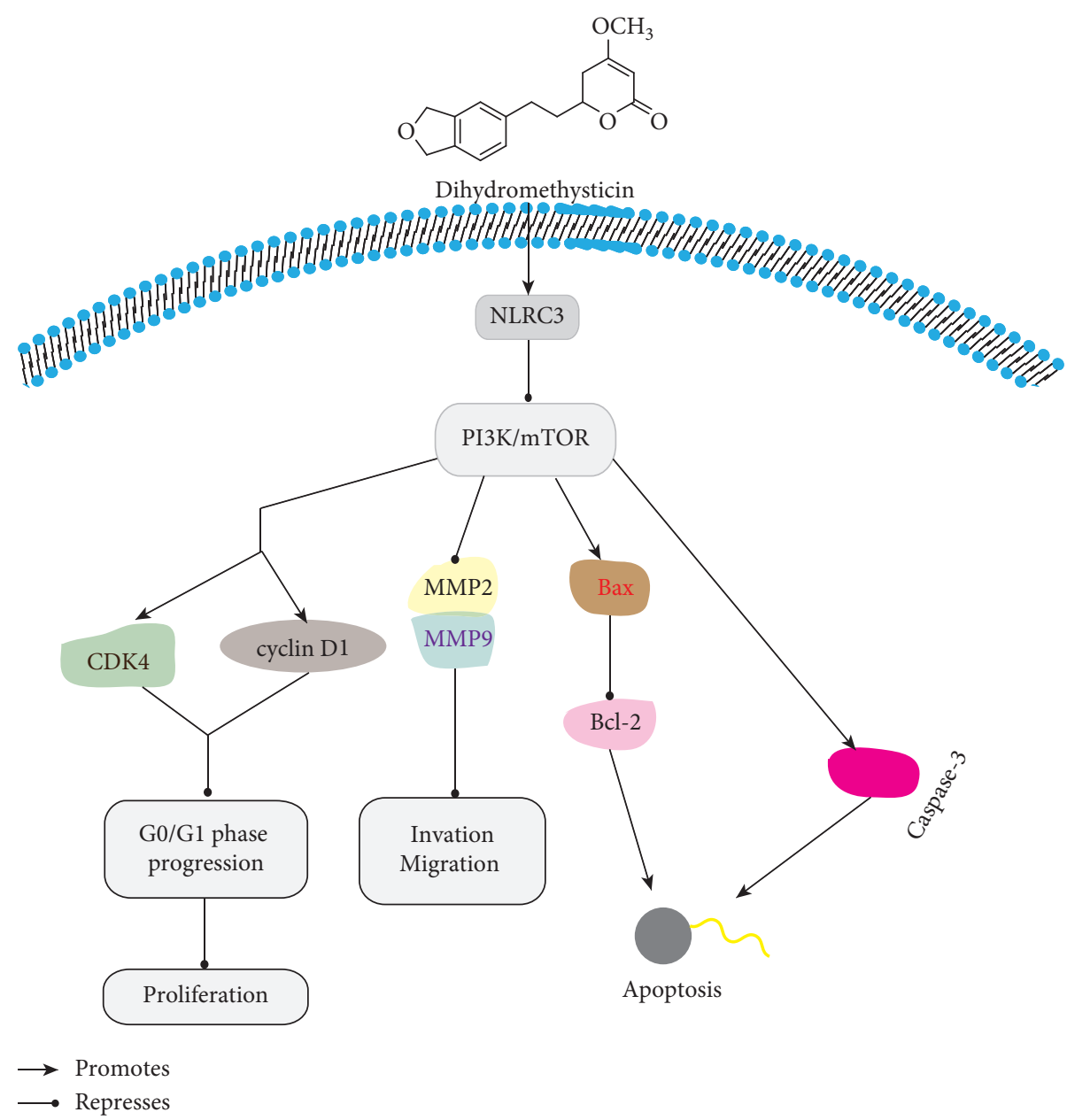

FIgURE 6: Proposed diagrams of DHM-induced G0/G1 phase arrest and apoptosis through phosphoinositide 3-kinase (PI3K)/nucleotideoligomerization domain-like receptor subfamily C3 (NLRC3) signaling pathway inhibition in colorectal cancer cells.<smiles>[R3]c1ccc(/C=C/c2cc(OC)cc(=O)o2)c(Br)c1Br</smiles>

FIGURE 7: The structure modification of kavalactone.

5,6-dehydrokavain, 6-phenyl-5-hexen-2,4-dione [85], p-hydroxy-5,6-dehydrokavain, and 6-phenyl-3-hexen-2-one [88]. In rats, approximately $50 \%$ to $75 \%$ of kavalactones were excreted as glucuronide and sulphate conjugates in the urine and $15 \%$ was in the bile [89-91]. The most frequent metabolic pathways for kavalactones in humans and rats included hydroxylation of the $\mathrm{C}-12$ in the aromatic ring, hydroxylation and cleavage of the lactone ring with subsequent dehydration, reduction of the 7,8-double bond, demethylation of the 4-methoxyl group, reduction of the double bond at carbons in positions 3 and 4 (to form a saturated pyrone ring system), and demethylation of the 4methoxy group in the $\alpha$-pyrone ring or of the 12-methoxy substituent in yangonin $[89,90,92]$.

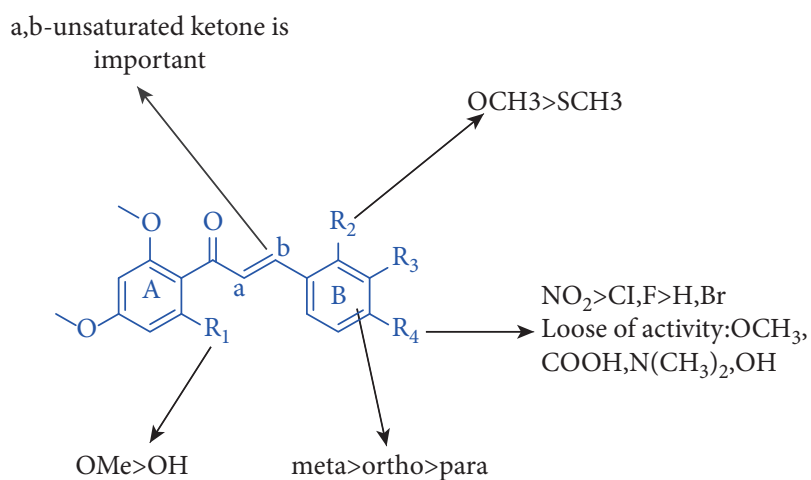

FIGURE 8: The structure-activity relationships of flavokawain.

\section{Conclusions and Future Perspectives}

Kava is a magical plant composed of various constituents, and furthermore, it possessed anxiolytic relaxant effects in the treatment of anxiety disorders and also exhibited the potential activities in cancer prevention and therapy. Phytochemical investigations on kava plant have resulted in the isolation and identification of at least $56 \mathrm{com}$ pounds. Among them, kavalactones and 
dihydrochalcones were found to be the most widely studied chemical classes. In the last two decades, the separation and determination methods of kava extractions have gone through several technological innovations. So far, many new techniques were also developed for the qualitative and quantitative analysis of kava. However, more efficient and effective analytical methods are needed to determine the content of bioactive constituents and other unknown compounds on kava quality assessment due to the safety concerns of hepatotoxicity and other adverse effects [93, 94]. In summary, the possible pathogenic factors leading to the occurrence of kava hepatotoxicity were as follows: (1) the quality of kava raw material might be the major factor [61]; (2) concomitant ingestion of other drugs with potential hepatotoxicity [9]; and (3) had the other unknown toxic components deriving from different kava extracts [11]. Research of kava hepatotoxicity faced multiple challenges because of the numerous compounds contained in kava extracts and limited number of affected patients [61]. Therefore, more clinical and experimental studies are needed to increase the knowledge of this field, and then, the relationship between kava and hepatotoxicitye can be elucidated in the future [70].

A number of studies have reported the anticancer activity of kava extraction or the isolated individual components. The most investigated compound of kava was found to be flavokavain B followed by flavokavain A, which all belong to the chalcone family but possess different substituents on their aryl rings. The biological activities of chalcones were associated with the presence of a double bond in conjugation with carbonyl functionality $[95,96]$. The mechanism of antiproliferative effect of kava was believed to be related with cell cycle arrest, induced apoptosis [97], and autophagy [42]. However, the role of autophagy was complex during the cancer therapy. As induced autophagy through the bioactive constituents of kava might become an attractive approach for cancer prevention and therapy in the future $[44,48]$, more investigations are required to identify the mechanism involved in this process. Meanwhile, the anticancer activity of kava was mainly focused on in vitro assessment, and only parts of studies were performed using in vivo models; current evidence from numerous clinical trials suggested the plant of kava was not sufficient to perform effective treatment for GAD. Therefore, future studies should be designed to fulfill these gaps. In order to give further information on the development of a new anticancer drug, more research is needed in the area of kava toxicity to explore the mechanisms of action on treat cancers, in the investigation of kava structure-activity relationship, and in the metabolism of kava. In summary, more clinical trials are needed to assess the effect of kava for treating GAD and the efficacy of kavalactones and flavokavains in treating cancers, and rational establishment of kava quality specifications will be beneficial for the general usages of kava. These reviews highlight areas for further research of kava constituents in the prevention and treatment of clinical diseases.

\author{
Abbreviations \\ ACC: Adenoid cystic carcinoma \\ ALL: $\quad$ Acute lymphoblastic leukemia \\ BMM: $\quad$ Bone marrow macrophages \\ COX: Cyclooxygenase \\ CRC: Colorectal cancer \\ DHM: Dihydromethysticin \\ ELISA: Enzyme-linked immunosorbent assay \\ FKA: Flavokawain A \\ FKB: $\quad$ Flavokawain B \\ FKC: Flavokawain C \\ GAD: Generalized anxiety disorder \\ HPLC: High-performance liquid chromatography \\ LPS: Lipopolysaccharide \\ MCF: Michigan cancer foundation \\ MTT: Methyl thiazolyl tetrazolium \\ NF- $\kappa$ B: Nuclear factor $-\kappa B$ \\ PCR: Polymerase chain reaction \\ PI3K: Phosphoinositide 3-kinase \\ Skp2: $\quad$ S phase kinase-associated protein 2 \\ TCa: Thyroid cancer \\ TGF: Transforming growth factor \\ TNF- $\alpha$ : Tumor necrosis factor- $\alpha$ \\ TRAMP: Transgenic adenocarcinoma of the mouse \\ prostate \\ WT: Wild type.
}

\section{Data Availability}

No data were used to support this study.

\section{Conflicts of Interest}

The authors have no conflicts of interest.

\section{Authors' Contributions}

Yingli Wang, Chao Su, and Bo Zhang contributed equally to this work.

\section{Acknowledgments}

This work was supported by the National Natural Science Foundation of China (Nos. 81860753 and 81560684), the Key Research and Development Program of Ningxia (2018BHF2001), Ningxia Key Research and Invention Program of Science and Technology Cooperation of the East and the West (Nos. 2018ZDKJ0219, 2017BY084, and 2017BY079), and the West Light Foundation of the Chinese Academy of Sciences-Young Scientists of West 2017.

\section{References}

[1] A. S. Aporosa, M. Atkins, and R. Brunton, "Kava drinking in traditional settings: towards understanding effects on cognitive function," Human Psychopharmacology, vol. 35, no. 2, p. e2725, 2020.

[2] A. F. Showman, J. D. Baker, C. Linares et al., "Contemporary Pacific and Western perspectives on 'awa (Piper methysticum) toxicology," Fitoterapia, vol. 100, pp. 56-67, 2015. 
[3] C. M. White, "The pharmacology, pharmacokinetics, efficacy, and adverse events associated with kava," The Journal of Clinical Pharmacology, vol. 58, no. 11, pp. 1396-1405, 2018.

[4] B. Cassileth, "Kava (Piper methysticum)," Oncology, vol. 25, no. 4, pp. 384-385, 2011.

[5] T. D. Xuan, M. Fukuta, A. C. Wei, A. A. Elzaawely, T. D. Khanh, and S. Tawata, "Efficacy of extracting solvents to chemical components of kava (Piper methysticum) roots," Journal of Natural Medicines, vol. 62, no. 2, pp. 188-194, 2008.

[6] M. n. Backleh, P. Ekici, G. n. Leupold, and H. Parlar, "Quantitative elimination of Flavokavines A and B from Kava Kava (Piper methysticum G. Forst) by isoelectric focused adsorptive bubble separation," Naturwissenschaften, vol. 90, no. 8, pp. 366-369, 2003.

[7] E. Mills, R. Singh, C. Ross, E. Ernst, and J. G. Ray, "Sale of kava extract in some health food stores," Canadian Medical Association Journal: Canadian Medical Association Journal = Journal de l'Association Medicale Canadienne, vol. 169, no. 11, pp. 1158-1159, 2003.

[8] C. Ulbricht, E. Basch, H. Boon et al., "Safety review of kava (Piper methysticum) by the natural standard research collaboration," Expert Opinion on Drug Safety, vol. 4, no. 4, pp. 779-794, 2005.

[9] J. Sarris, E. LaPorte, and I. Schweitzer, "Kava: a comprehensive review of efficacy, safety, and psychopharmacology," Australian and New Zealand Journal of Psychiatry, vol. 45, no. 1, pp. 27-35, 2011.

[10] S. Hannam, M. Murray, L. Romani, M. Tuicakau, and M. J. Whitfeld, "Kava dermopathy in Fiji: an acquired ichthyosis?" International Journal of Dermactology, vol. 53, no. 12, pp. 1490-1494, 2014.

[11] R. Teschke, "Kava hepatotoxicity: pathogenetic aspects and prospective considerations," Liver International, vol. 30, no. 9, pp. 1270-1279, 2010.

[12] R. Teschke, "Kava hepatotoxicity—a clinical review," Annals of Hepatology, vol. 9, no. 3, pp. 251-265, 2010.

[13] I. Wainiqolo, B. Kafoa, B. Kool et al., "Driving following kava use and road traffic injuries: a population-based case-control study in Fiji (trip 14)," PLoS One, vol. 11, no. 3, Article ID e149719, 2016.

[14] I. Wainiqolo, B. Kool, V. Nosa, and S. Ameratunga, "Is driving under the influence of kava associated with motor vehicle crashes? A systematic review of the epidemiological literature," Australian and New Zealand Journal of Public Health, vol. 39, no. 5, pp. 495-499, 2015.

[15] K. Savage, J. Firth, C. Stough, and J. Sarris, "GABA-modulating phytomedicines for anxiety: a systematic review of preclinical and clinical evidence," Phytotherapy Research, vol. 32, no. 1, pp. 3-18, 2018.

[16] A. R. Bilia, L. Scalise, M. C. Bergonzi, and F. F. Vincieri, "Analysis of kavalactones from Piper methysticum (kavakava)," Journal of Chromatography B: Analytical Technologies in the Biomedical and Life Sciences, vol. 812, no. 1-2, pp. 203-214, 2004.

[17] Y. Yuan, J. X. Yang, L. H. Nie et al., "Three new kavalactone dimers from Piper methysticum (kava)," Journal of Asian Natural Products Research, pp. 1-7, 2017.

[18] J. L. Song, B. L. Li, Y. Yuan et al., "Yangonindimers A-C, three new kavalactone dimers from Piper methysticum (kava)," Natural Product Research, vol. 31, no. 21, pp. 2459-2466, 2017.

[19] J. X. Yang, "A new kavalactone dimer from Piper methysticum," Chemistry of Natural Compounds, vol. 55, no. 4, pp. 606-609, 2019.
[20] V. Lebot, T. K. Do, and L. Legendre, "Detection of flavokavins (A, B, C) in cultivars of kava (Piper methysticum) using high performance thin layer chromatography (HPTLC)," Food Chemistry, vol. 151, pp. 554-560, 2014.

[21] D. Wu, M. G. Nair, and D. L. DeWitt, "Novel compounds from Piper methysticum Forst (Kava Kava) roots and their effect on cyclooxygenase enzyme," Journal of Agricultural and Food Chemistry, vol. 50, no. 4, pp. 701-705, 2002.

[22] T. M. Van, T. D. Xuan, T. N. Minh, and N. V. Quan, "Isolation and purification of potent growth inhibitors from Piper methysticum root," Molecules, vol. 23, no. 8, 2018.

[23] R. Tsutsui, K. Shinomiya, Y. Takeda, Y. Obara, Y. Kitamura, and C. Kamei, "Hypnotic and sleep quality-enhancing properties of kavain in sleep-disturbed rats," Journal of Pharmacological Sciences, vol. 111, no. 3, pp. 293-298, 2009.

[24] X. Tang and S. Amar, "Kavain involvement in LPS-induced signaling pathways," Journal of Cellular Biochemistry, vol. 117, no. 10, pp. 2272-2280, 2016.

[25] X. Tang, M. Alasiri, A. Bamashmous et al., "The involvement of Kav001 in inhibition of LPS/P. gingivalis-induced," Journal of Cellular Biochemistry, vol. 119, no. 7, pp. 6072-6079, 2018.

[26] D. J. Kwon, S. M. Ju, G. S. Youn, S. Y. Choi, and J. Park, "Suppression of iNOS and COX-2 expression by flavokawain A via blockade of NF-kappaB and AP-1 activation in RAW 264.7 macrophages," Food and Chemical Toxicology, vol. 58, pp. 479-486, 2013.

[27] A. Alshammari, J. Patel, J. Al-Hashemi et al., "Kava-241 reduced periodontal destruction in a collagen antibody primed Porphyromonas gingivalis model of periodontitis," Journal of Clinical Periodontology, vol. 44, no. 11, pp. 1123-1132, 2017.

[28] O. Huck, J. You, X. Han, B. Cai, J. Panek, and S. Amar, "Reduction of articular and systemic inflammation by kava241 in a porphyromonas gingivalis-induced arthritis murine model," Infection and Immunity, vol. 86, no. 9, 2018.

[29] C. W. Phang, S. A. Karsani, and M. S. Abd, "Induction of apoptosis and cell cycle arrest by flavokawain C on HT-29 human colon adenocarcinoma via enhancement of reactive oxygen species generation, upregulation of p21, p27, and GADD153, and inactivation of inhibitor of apoptosis proteins," Pharmacognosy Magazine, vol. 13, no. S2, pp. S321-S328, 2017.

[30] A. Palko-Łabuz, E. Kostrzewa-Susłow, T. Janeczko et al., "Cyclization of flavokawain B reduces its activity against human colon cancer cells," Human and Experimental Toxicology, vol. 39, no. 3, pp. 262-275, 2020.

[31] H. Pan, F. Liu, J. Wang et al., "Dihydromethysticin, a natural molecule from kava, suppresses the growth of colorectal cancer via the NLRC3/PI3K pathway," Molecular Carcinogenesis, vol. 59, no. 6, pp. 575-589, 2020.

[32] J. An, Y. Gao, J. Wang et al., "Flavokawain B induces apoptosis of non-small cell lung cancer $\mathrm{H} 460$ cells via Bax-initiated mitochondrial and JNK pathway," Biotechnology Letters, vol. 34, no. 10, pp. 1781-1788, 2012.

[33] J. F. Botello, P. Corral, T. Bian, and C. Xing, "Kava and its kavalactones inhibit norepinephrine-induced intracellular calcium influx in lung cancer cells," Planta Medica, vol. 86, no. 1, pp. 26-31, 2020.

[34] S. C. Narayanapillai, S. H. Lin, P. Leitzman, P. Upadhyaya, C. J. Baglole, and C. Xing, "Dihydromethysticin (DHM) blocks tobacco carcinogen 4-(Methylnitrosamino)-1-(3-pyridyl)-1-butanone (NNK)-Induced $\mathrm{O}(6)$-methylguanine in a manner independent of the aryl hydrocarbon receptor (AhR) pathway in C57BL/6 female mice," Chemical Research in Toxicology, vol. 29, no. 11, pp. 1828-1834, 2016. 
[35] J. Q. Dai, Y. G. Huang, and A. N. He, "Dihydromethysticin kavalactone induces apoptosis in osteosarcoma cells through modulation of PI3K/Akt pathway, disruption of mitochondrial membrane potential and inducing cell cycle arrest," International Journal of Clinical and Experimental Pathology, vol. 8, no. 5, pp. 4356-4366, 2015.

[36] T. Ji, C. Lin, L. S. Krill et al., "Flavokawain B, a kava chalcone, inhibits growth of human osteosarcoma cells through G2/M cell cycle arrest and apoptosis," Molecular Cancer, vol. 12, no. no, p. 55, 2013.

[37] Y. Zhang, Y. S. Zvi, B. Batko et al., "Down-regulation of Skp2 expression inhibits invasion and lung metastasis in osteosarcoma," Scientific Reports, vol. 8, no. 1, p. 14294, 2018.

[38] T. Sakai, R. N. Eskander, Y. Guo et al., "Flavokawain B, a kava chalcone, induces apoptosis in synovial sarcoma cell lines," Journal of Orthopaedic Research, vol. 30, no. 7, pp. 1045-1050, 2012.

[39] N. Abu, M. N. Akhtar, S. K. Yeap et al., "Flavokawain A induces apoptosis in MCF-7 and MDA-MB231 and inhibits the metastatic process in vitro," PLoS One, vol. 9, no. 10, Article ID e105244, 2014.

[40] N. Abu, M. N. Akhtar, S. K. Yeap et al., "Flavokawain B induced cytotoxicity in two breast cancer cell lines, MCF-7 and MDA-MB231 and inhibited the metastatic potential of MDA-MB231 via the regulation of several tyrosine kinases in vitro," BMC Complementary and Alternative Medicine, vol. 16, p. 86, 2016.

[41] Q. He, W. Liu, S. Sha et al., “Adenosine 5'-monophosphateactivated protein kinase-dependent mTOR pathway is involved in flavokawain B-induced autophagy in thyroid cancer cells," Cancer Science, vol. 109, no. 8, pp. 2576-2589, 2018.

[42] C. T. Chang, Y. C. Hseu, V. Thiyagarajan et al., "Chalcone flavokawain $\mathrm{B}$ induces autophagic-cell death via reactive oxygen species-mediated signaling pathways in human gastric carcinoma and suppresses tumor growth in nude mice," Archives of Toxicology, vol. 91, no. 10, pp. 3341-3364, 2017.

[43] Z. Liu, X. Xu, X. Li et al., "Kava chalcone, flavokawain A, inhibits urothelial tumorigenesis in the UPII-SV40T transgenic mouse model," Cancer Prevention Research, vol. 6, no. 12, pp. 1365-1375, 2013.

[44] Z. Liu, U. S. Ha, K. Yu, C. Wu, N. Yokoyama, and X. Zi, "Kavalactone yangonin induces autophagy and sensitizes bladder cancer cells to flavokawain A and docetaxel via inhibition of the mTOR pathway," Journal of biomedical research, vol. 31, no. 5, pp. 408-418, 2017.

[45] X. Li, V. Pham, M. Tippin et al., "Flavokawain B targets protein neddylation for enhancing the anti-prostate cancer effect of Bortezomib via Skp2 degradation," Cell Communication and Signaling, vol. 17, no. 1, p. 25, 2019.

[46] K. Wang, W. Zhang, Z. Wang et al., "Flavokawain A inhibits prostate cancer cells by inducing cell cycle arrest and cell apoptosis and regulating the glutamine metabolism pathway," Journal of Pharmaceutical and Biomedical Analysis, vol. 186, Article ID 113288, 2020.

[47] S. N. Tang, J. Zhang, P. Jiang et al., "Gene expression signatures associated with suppression of TRAMP prostate carcinogenesis by a kavalactone-rich kava fraction," Molecular Carcinogenesis, vol. 55, no. 12, pp. 2291-2303, 2016.

[48] J. Wang, Q. Qi, W. Zhou et al., "Inhibition of glioma growth by flavokawain B is mediated through endoplasmic reticulum stress induced autophagy," Autophagy, vol. 14, no. 11, pp. 2007-2022, 2018.

[49] R. N. Eskander, L. M. Randall, T. Sakai, Y. Guo, B. Hoang, and X. Zi, "Flavokawain B, a novel, naturally occurring chalcone, exhibits robust apoptotic effects and induces G2/M arrest of a uterine leiomyosarcoma cell line," Journal of Obstetrics and Gynaecology Research, vol. 38, no. 8, pp. 1086-1094, 2012.

[50] Y. C. Hseu, M. S. Lee, C. R. Wu et al., "The chalcone flavokawain B induces $\mathrm{G} 2 / \mathrm{M}$ cell-cycle arrest and apoptosis in human oral carcinoma HSC-3 cells through the intracellular ROS generation and downregulation of the Akt/p38 MAPK signaling pathway," Journal of Agricultural and Food Chemistry, vol. 60, no. 9, pp. 2385-2397, 2012.

[51] X. Zhao, Y. L. Chao, Q. B. Wan et al., "Flavokawain B induces apoptosis of human oral adenoid cystic cancer ACC-2 cells via up-regulation of Bim and down-regulation of Bcl-2 expression," Canadian Journal of Physiology and Pharmacology, vol. 89, no. 12, pp. 875-883, 2011.

[52] E. Lin, W. H. Lin, S. Y. Wang et al., "Flavokawain B inhibits growth of human squamous carcinoma cells: involvement of apoptosis and cell cycle dysregulation in vitro and in vivo," Journal of Nutritional Biochemistry, vol. 23, no. 4, pp. 368-378, 2012.

[53] Y. L. Tang, L. B. Huang, Y. Tian et al., "Flavokawain B inhibits the growth of acute lymphoblastic leukemia cells via p53 and caspase-dependent mechanisms," Leukemia and Lymphoma, vol. 56, no. 8, pp. 2398-2407, 2015.

[54] S. K. Yeap, N. Abu, N. Akthar et al., "Gene expression analysis reveals the concurrent activation of proapoptotic and antioxidant-defensive mechanisms in flavokawain B-treated cervical cancer HeLa cells," Integrative Cancer Therapies, vol. 16, no. 3, pp. 373-384, 2017.

[55] M. C. Rossette, D. C. Moraes, E. K. Sacramento et al., "The in vitro and in vivo antiangiogenic effects of flavokawain B," Pharmaceutical Biology, vol. 31, no. 10, pp. 1607-1613, 2017.

[56] Y. C. Hseu, T. Y. Yang, M. L. Li et al., "Chalcone flavokawain A attenuates TGF-betal-induced fibrotic pathology via inhibition of ROS/Smad3 signaling pathways and induction of Nrf2/ARE-mediated antioxidant genes in vascular smooth muscle cells," Journal of Cellular and Molecular Medicine, vol. 23, no. 2, pp. 775-788, 2019.

[57] N. Abu, N. E. Mohameda, N. Tangarajoo et al., "In vitro toxicity and in vivo immunomodulatory effects of flavokawain A and flavokawain B in balb/C mice," Natural Product Communications, vol. 10, no. 7, pp. 1199-1202, 2015.

[58] B. Tengfei, C. Pedro, W. Yuzhi et al., "Kava as a clinical nutrient: promises and challenges," Nutrients, vol. 12, no. 10, 2020.

[59] S. Strahl, V. Ehret, H. H. Dahm, and K. P. Maier, "Necrotizing hepatitis after taking herbal remedies," Deutsche Medizinische Wochenschrift, vol. 123, no. 47, pp. 1410-1414, 1998.

[60] K. Smith and C. Leiras, "The effectiveness and safety of Kava kava for treating anxiety symptoms: a systematic review and analysis of randomized clinical trials," Complementary Therapies in Clinical Practice, vol. 33, pp. 107-117, 2018.

[61] R. Teschke, S. X. Qiu, and V. Lebot, "Herbal hepatotoxicity by kava: update on pipermethystine, flavokavain B, and mould hepatotoxins as primarily assumed culprits," Digestive and Liver Disease, vol. 43, no. 9, pp. 676-681, 2011.

[62] M. W. Becker, E. Lourencone, A. F. De Mello et al., "Liver transplantation and the use of kava: case report," Phytomedicine, vol. 56, pp. 21-26, 2019.

[63] R. Teschke, A. Genthner, and A. Wolff, "Kava hepatotoxicity: comparison of aqueous, ethanolic, acetonic kava extracts and kava-herbs mixtures," Journal of Ethnopharmacology, vol. 123, no. 3, pp. 378-384, 2009. 
[64] R. Teschke, A. Schwarzenboeck, and A. Akinci, "Kava hepatotoxicity: a European view," New Zealand Medical Journal, vol. 121, no. 1283, pp. 90-98, 2008.

[65] R. Teschke, A. Genthner, A. Wolff, C. Frenzel, J. Schulze, and A. Eickhoff, "Herbal hepatotoxicity: analysis of cases with initially reported positive re-exposure tests," Digestive and Liver Disease, vol. 46, no. 3, pp. 264-269, 2014.

[66] P. V. Nerurkar, K. Dragull, and C. S. Tang, "In vitro toxicity of kava alkaloid, pipermethystine, in HepG2 cells compared to kavalactones," Toxicological Sciences, vol. 79, no. 1, pp. 106-111, 2004.

[67] S. T. Lim, K. Dragull, C. S. Tang, H. C. Bittenbender, J. T. Efird, and P. V. Nerurkar, "Effects of kava alkaloid, pipermethystine, and kavalactones on oxidative stress and cytochrome P450 in F-344 rats," Toxicological Sciences, vol. 97, no. 1, pp. 214-221, 2007.

[68] J. W. Jhoo, J. P. Freeman, T. M. Heinze et al., "In vitro cytotoxicity of nonpolar constituents from different parts of kava plant (Piper methysticum)," Journal of Agricultural and Food Chemistry, vol. 54, no. 8, pp. 3157-3162, 2006.

[69] P. Zhou, S. Gross, J. H. Liu et al., "Flavokawain B, the hepatotoxic constituent from kava root, induces GSH-sensitive oxidative stress through modulation of IKK/NF-kappaB and MAPK signaling pathways," The FASEB Journal, vol. 24, no. 12, pp. 4722-4732, 2010.

[70] F. Pantano, R. Tittarelli, G. Mannocchi et al., "Hepatotoxicity induced by "the $3 \mathrm{Ks}$ ": kava, kratom and khat," International Journal of Molecular Sciences, vol. 17, no. 4, p. 580, 2016.

[71] B. Cai, J. S. Panek, and S. Amar, "Kava analogues as agents for treatment of periodontal diseases: synthesis and initial biological evaluation," Bioorganic and Medicinal Chemistry Letters, vol. 28, no. 16, pp. 2667-2669, 2018.

[72] M. P. Pollastri, A. Whitty, J. C. Merrill, X. Tang, T. D. Ashton, and S. Amar, "Identification and characterization of kavaderived compounds mediating TNF-alpha suppression," Chemical Biology and Drug Design, vol. 74, no. 2, pp. 121-128, 2009.

[73] T. Tomita, "Apoptosis in pancreatic beta-islet cells in type 2 diabetes," Bosnian Journal of Basic Medical Sciences, vol. 16, no. 3, pp. 162-179, 2016.

[74] T. Pluskal, M. P. Torrens-Spence, T. R. Fallon, A. De Abreu, C. H. Shi, and J. K. Weng, "The biosynthetic origin of psychoactive kavalactones in kava," Nature Plants, vol. 5, no. 8, pp. 867-878, 2019.

[75] H. Herath, A. C. Taki, N. Nguyen et al., "Synthetic kavalactone analogues with increased potency and selective anthelmintic activity against larvae of Haemonchus contortus in vitro," Molecules, vol. 25, no. 8, 2020.

[76] O. Huck, X. Han, H. Mulhall et al., "Identification of a kavain analog with efficient anti-inflammatory effects," Scientific Reports, vol. 9, no. 1, p. 12940, 2019.

[77] E. C. Kormann, P. de Aguiar Amaral, M. David, V. L. EiflerLima, V. C. Filho, and F. de Campos Buzzi, "Kavain analogues as potential analgesic agents," Pharmacological Reports, vol. 64, no. 6, pp. 1419-1426, 2012.

[78] A. J. Leon-Gonzalez, N. Acero, D. Munoz-Mingarro, I. Navarro, and C. Martin-Cordero, "Chalcones as promising lead compounds on cancer therapy," Current Medicinal Chemistry, vol. 22, no. 30, pp. 3407-3425, 2015.

[79] D. K. Mahapatra, V. Asati, and S. K. Bharti, "Chalcones and their therapeutic targets for the management of diabetes: structural and pharmacological perspectives," European Journal of Medicinal Chemistry, vol. 92, pp. 839-865, 2015.
[80] A. Abu Bakar, M. N. Akhtar, N. Mohd Ali et al., "Design, synthesis and docking studies of flavokawain $\mathrm{B}$ type chalcones and their cytotoxic effects on MCF-7 and MDA-MB-231 cell lines," Molecules, vol. 23, no. 3, p. 616, 2018.

[81] C. W. Mai, M. Yaeghoobi, N. Abd-Rahman, Y. B. Kang, and M. R. Pichika, "Chalcones with electron-withdrawing and electron-donating substituents: anticancer activity against TRAIL resistant cancer cells, structure-activity relationship analysis and regulation of apoptotic proteins," European Journal of Medicinal Chemistry, vol. 77, pp. 378-387, 2014.

[82] C. Thieury, N. Lebouvier, R. Le Guével et al., "Mechanisms of action and structure-activity relationships of cytotoxic flavokawain derivatives," Bioorganic and Medicinal Chemistry, vol. 25, no. 6, pp. 1817-1829, 2017.

[83] C. Pouget, F. Lauthier, A. Simon et al., "Flavonoids: structural requirements for antiproliferative activity on breast cancer cells," Bioorganic and Medicinal Chemistry Letters, vol. 11, no. 24, pp. 3095-3097, 2001.

[84] Y. Swee Keong, N. Mohd Ali, N. M. Akhtar et al., "Flavokawain derivative FLS induced G2/M arrest and apoptosis on breast cancer MCF-7 cell line," Drug Design, Development and Therapy, vol. 10, pp. 1897-1907, 2016.

[85] F. Tarbah, H. Mahler, B. Kardel, W. Weinmann, D. Hafner, and T. Daldrup, "Kinetics of kavain and its metabolites after oral application," Journal of Chromatography B: Analytical Technologies in the Biomedical and Life Sciences, vol. 789, no. 1, pp. 115-130, 2003.

[86] A. Volgin, L. Yang, T. Amstislavskaya et al., "DARK classics in chemical neuroscience: kava," ACS Chemical Neuroscience, 2020.

[87] B. M. Johnson, S. X. Qiu, S. Zhang et al., "Identification of novel electrophilic metabolites of Piper methysticum forst (kava)," Chemical Research in Toxicology, vol. 16, no. 6, pp. 733-740, 2003.

[88] L. Zou, M. R. Harkey, and G. L. Henderson, "Synthesis, in vitro, reactivity, and identification of 6-phenyl-3-hexen-2-one in human urine after kava-kava (Piper methysticum) ingestion," Planta Medica, vol. 71, no. 2, pp. 142-146, 2005.

[89] A. M. Duffield, D. D. Jamieson, R. O. Lidgard, P. H. Duffield, and D. J. Bourne, "Identification of some human urinary metabolites of the intoxicating beverage kava," Journal of Chromatography A, vol. 475, pp. 273-281, 1989.

[90] C. Koppel and J. Tenczer, "Mass spectral characterization of urinary metabolites of D, L-kawain," Journal of Chromatography $B$, vol. 562, no. 1-2, pp. 207-211, 1991.

[91] J. M. Mathews, A. S. Etheridge, J. L. Valentine et al., "Pharmacokinetics and disposition of the kavalactone kawain: interaction with kava extract and kavalactones in vivo and in vitro," Drug Metabolism and Disposition, vol. 33, no. 10, pp. 1555-1563, 2005.

[92] A. Rowe, L. Y. Zhang, and I. Ramzan, "Toxicokinetics of kava," Advances in Pharmacological Sciences, vol. 2011, Article ID 326724, 6 pages, 2011.

[93] Y. Liu, J. A. Lund, S. J. Murch, and P. N. Brown, "Single-lab validation for determination of kavalactones and flavokavains in Piper methysticum (kava)," Planta Medica, vol. 84, no. 16, 2018.

[94] G. E. Petersen, Y. Tang, and C. Fields, "Chemical and in vitro toxicity analysis of a supercritical fluid extract of Kava kava (Piper methysticum)," Journal of Ethnopharmacology, vol. 235, pp. 301-308, 2019.

[95] P. Singh, A. Anand, and V. Kumar, "Recent developments in biological activities of chalcones: a mini review," European Journal of Medicinal Chemistry, vol. 85, pp. 758-777, 2014. 
[96] Z. Rozmer and P. Perjési, "Naturally occurring chalcones and their biological activities," Phytochemistry Reviews, vol. 15, no. 1, pp. 87-120, 2016.

[97] A. Celentano, A. Tran, C. Testa et al., "The protective effects of kava (Piper methysticum) constituents in cancers: a systematic review," Journal of Oral Pathology and Medicine, vol. 48, no. 7, pp. 510-529, 2019. 